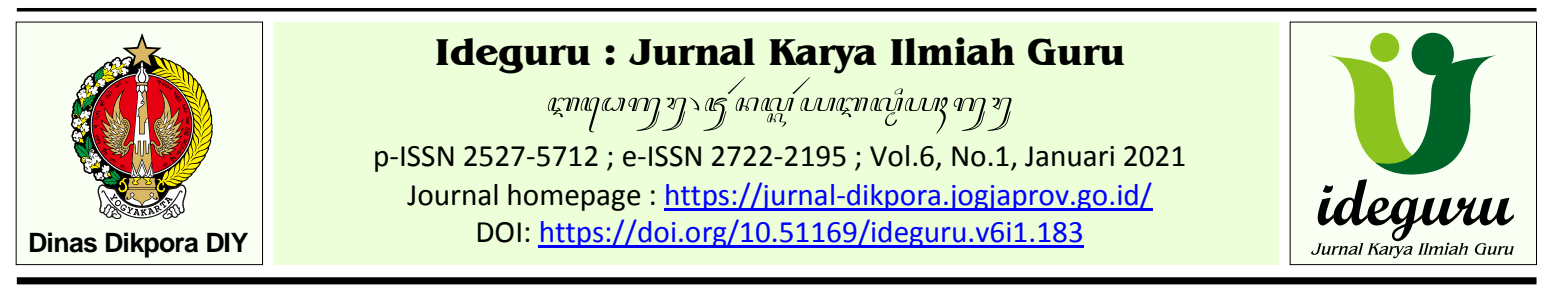

Best Practice - Naskah dikirim: 10/12/2020 - Selesai revisi: 10/03/2021 - Disetujui: 12/03/2021 - Diterbitkan: 15/03/2021

\title{
Penerapan Metode Kepemimpinan Transformasional untuk Mewujudkan Sekolah Sehat
}

\author{
Heri Prasetya \\ SMPN 2 Kasihan \\ prasetyaheri935@gmail.com
}

\begin{abstract}
Abstrak : Penulisan Best Practice ini bertujuan untuk mengetahui penerapan metode kepemimpinan transformasional dapat mewujudkan Sekolah Sehat di SMPN 2 Kasihan. Metode penulisan Best Practice ini menggunakan pendekatan kualitatif dengan metode studi kasus karena penulisan Best Practice ini bertujuan untuk menggali informasi dengan mempertahankan keutuhan subjek penulisan sebagai satu kesatuan yakni Best Practice penyelenggaraan sekolah dengan metode kepemimpinan transformasional di SMPN 2 Kasihan. Penulisan Best Practice ini menggali informasi dengan teknik, observasi, angket dan studi dokumen untuk dianalisis dan diinterpretasikan. Hasil penerapan metode kepemimpinan transformasional menunjukkan bahwa nilai rata-rata sekolah sehat sebelum dilaksanakan tindakan sebesar 2.5 dengan kualifikasi Cukup dan setelah dilakukan tindakan meningkat menjadi rata-rata 3.64 atau meningkat 45.6\% dengan kualifikasi Baik. Kualitas lingkungan sekolah mengalami peningkatan dari rata-rata 2.4 sebelum tindakan dan setelah tindakan mencapai rata-rata 3.4 atau peningkatan sebesar $41.66 \%$. Kualitas budaya hidup bersih dan sehat juga mengalami peningkatan dari sebelum tindakan rata-rata 2.75 atau Cukup menjadi rata-rata 3.88 atau Baik, dengan peningkatan kualitas sebesar 41.09\%. Berdasarkan hasil tersebut dapat disimpulkan bahwa penerapan metode kepemimpinan transformasional dapat mewujudkan Sekolah Sehat di SMPN 2 Kasihan.
\end{abstract}

Kata Kunci: kepemimpinan transformasional, perilaku hidup bersih dan sehat, sekolah sehat

\section{The Application of Transformational Leadership Method to Create a Healthy School}

\begin{abstract}
This Best Practice writing is intended to determine whether the application of transformational leadership method could create a Healthy School at SMPN 2 Kasihan. This writing uses qualitative approach with the cases study, which is intended for collecting information with maintaining the integrity of the writing subject, which is implementation of the Best Practice with transformational leadership method as an implementation at SMPN 2 Kasihan. Its collect data with technique, observation, questionnaire, and documents study to be analyzed and interpreted. The result shows that the average score of healthy school before it was implemented was 2.5 with "Enough" qualification, while it increases to 3.64 or $45.6 \%$ with "Good" qualification higher than before, or after the implementation of tranformational leadership method. The quality of the school environment also raised from 2.4 to 3.4, with a $41.66 \%$ increased. Quality of Clean and Healthy Lifestyle also had a spike from 2.75 "Enough" to 3.88 "Good", with a $41.09 \%$ increased. Based on the result, It can be concluded that the transformational leadership method could create a Healthy School at SMPN 2 Kasihan.
\end{abstract}

Keywords: leadership transformational, clean and healthy life, healthy school

\section{Pendahuluan}

Bapak Pendidikan Nasional Ki Hadjar Dewantara menggambarkan bahwa sekolah adalah sebuah "Taman", filosofi ini menggambarkan bahwa sekolah harus merupakan tempat yang secara fisik menyenangkan karena sejuk, asri, dan rindang, selain itu secara psikis sekolah menjadi tempat individu untuk berinteraksi sosial secara menyenangkan. Ki Hadjar Dewantara meletakkan dasar bahwa sekolah haruslah menjadi tempat yang menyenangkan dan belajar adalah proses kegembiraan untuk meningkatkan kualitas hidup manusia. Sekolah harus tumbuh sebagai taman yaitu tempat para siswa mendapatkan banyak banyak sumber belajar sekaligus menjadi suatu tempat yang menyenangkan untuk tumbuh dan berkembang baik jasmani dan rohani secara sehat. 
Guna mewujudkan berkembangnya jasmani dan rohani secara sehat, Kementerian Pendidikan dan Kebudayaan telah mengeluarkan Permendikbud Nomor 23 Tahun 2015 tentang Penumbuhan Budi Pekerti. Salah satu poin penting dari Permendikbud tersebut adalah upaya membudayakan perilaku hidup bersih dan sehat di sekolah.

Sekolah Sehat Berkarakter (SSB) adalah sekolah yang membangun peserta didik sebagai insan sehat dan mengembangkan potensi psikososialnya yang mencerminkan nilai religius, nasionalis, mandiri, gotong royong, dan integritas. Sekolah Sehat berkarakter melaksanakan program Usaha Kesehatan Sekolah (UKS) yang bertumpu pada tiga aspek yaitu; fisik, nonfisik, dan personal dalam pembiasaan Perilaku Hidup Bersih dan Sehat (PHBS) peserta didik sebagai budaya hidup.

Berdasarkan hasil observasi yang dilaksanakan oleh kepala sekolah fenomena yang terjadi di SMP 2 Kasihan yang berkaitan dengan lingkungan sekolah dan perilaku hidup sehat adalah sebagai berikut: 1) lingkungan sekolah yang cenderung kotor, tidak tertata dengan baik; 2) taman yang terkesan tertata apa adanya; 3) sekolah tidak memiliki kantin, sehingga siswa jajan di luar sekolah yang tidak terjamin kesehatannya; 4) Sekolah tidak memiliki ruang Usaha Kesehatan Sekolah (UKS) yang reperesntatif dan permanen karena hanya dittipkan di ruang Bimbingan Konseling, sehingga penanganan di UKS tidak maksimal; 5) masih ditemukan siswa membuang sampah sembarangan, siswa sebelum makan tidak mencuci tangan terlebih dahulu, bahwa masih ada siswa yang membiarkan rambut dan kuku memanjang tidak terawat, menderita gigi berlubang, kurang bersih dan rapi dalam berpakaian, kurang serius dalam melaksanakan senam setiap jumat pagi, jajan sembarangan dan tidak memperhatikan kebersihan jajanan.

Berdasar hal tersebut di atas maka SMPN 2 Kasihan belum dikatakan sebagai sekolah yang sehat karena pengelolaan kebersihan lingkungan masih rendah serta perilaku hidup bersih dan sehat masih rendah. Padahal tuntutan yang ada untuk sekolah adalah sebagai taman yang indah dan tempat berseminya Perilaku Hidup Bersih dan Sehat (PHBS).

Sebagai kepala sekolah menyadari bahwa tidak mudah mengubah keadaan lingkungan yang kurang sehat dan perilaku yang belum mendukung terbentuknya sekolah yang sehat. Guna mengubah keadaan seperti itu maka penulis menyadari bahwa yang harus dibenahi adalah sumber daya manusianya yaitu para guru, karyawan dan para siswa. Para guru dan karyawan akan menjadi baik kalau dipimpin oleh kepala sekolah dengan kepemimpinan yang baik. Oleh karena itu diperlukan metode kepemimpinan yang tepat yang yang mampu meningkatkan kualitas dan kinerja para guru dan karyawan.

Guna mencapai tujuan di atas maka dilakukan studi pustaka untuk memilih dan memilah dari bermacam-macam metode kepemimpinan yang sekiranya mampu menjawab permasalahan di atas, yang pada akhirnya penulis sampai pada sebuah keputusan untuk memilih metode kepemimpinan transformasional sebagai salah satu metode kepemimpinan untuk menciptakan sekolah sehat.

Berdasarkan latar belakang, identifikasi masalah dan pembatasan masalah yang dikemukakan di atas, maka perumusan masalah ini adalah: Bagaimanakah penerapan metode Kepemimpinan transformasional dapat mewujudkan sekolah sehat di SMPN 2 Kasihan?. Adapun tujuan penulisan Best Practice ini adalah untuk mengetahui penerapan metode Kepemimpinan transformasional dapat mewujudkan sekolah sehat di SMPN 2 Kasihan.

\section{Tinjauan Pustaka}

Hakekat sekolah sehat adalah sekolah yang memiliki lingkungan fisik dan lingkungan sosial yang sehat, serta terdapat kebiasaan atau perilaku hidup sehat dari seluruh warga sekolah. Sekolah sehat memiliki manfaat yang besar untuk jangka pendek maupun jangka panjang. Seperti yang tercantum dalam Buku Panduan Pengembangan Model Sekolah Sehat di Indonesia (Kemendiknas, 2009: 4) bahwa manfaat sekolah sehat bukan hanya bagi sekolah saja namun sekolah sehat memiliki manfaat juga bagi pemerintah karena sekolah sehat turut membantu pemerintah dalam mewujudkan sumber daya manusia yang berkualitas. Selain itu sekolah yang sehat akan juga menjadi alasan menarik bagi dunia industri dan instansi swasta untuk berkontribusi terhadap pengembangan sekolah.

Sekolah sehat sangat bermanfaat bagi perkembangan fisik dan mental siswa, secara fisik para siswa akan semakin tinggi tingkat kesehatannnya dan secara mental akan meningkatkan kualitas karakter siswa terutama karakter mandiri. Seperti yang disampaikan oleh Badan Penelitian dan Pengembangan Kementerian Pendidikan dan Kebudayaan (2017: 44) bahwa sekolah sehat melatih kemandirian yaitu kemandirian bagi sekolah dan kemandirian bagi siswa. Kemandirian bagi sekolah yaitu sikap 
memiliki inisiatif sendiri dan tidak tergantung pada pihak lain dalam mewujudkan lingkungan yang bersih rapi, dan hijau. Bagi siswa kemandirian dalam berperilaku sehat dan dalam mewujudkan pribadi yang sehat baik secara jasmani dan rohani. Lebih lanjut dikatakan bahwa kemandirian dalam berperilaku sehat akan memberikan sumbangan yang besar dalam mewujudkan generasi berprestasi.

Terwujudnya sekolah sehat sangat dipengaruhi oleh lingkungan fisik sekolah yang memenuhi kriteria sesuai standar pendidikan. Seperti yang disampaikan oleh Kemendiknas Direktorat Jenderal Pendidikan Dasar (2009: 9) bahwa sekolah sehat itu bukan hanya memiliki kebiasaan hidup sehat bagi seluruh warga sekolah namun juga harus memiliki lingkungan fisik yang memadai seperti bangunan sekolah yang memenuhi standar dan memiliki pagar yang cukup serta ruang olah raga yang terbuka.

Senada dengan itu menurut Buku Pedoman Gerakan Sekolah Sehat, Aman, Ramah Anak, dan Menyenangkan yang dikeluarkan Kemendikbud (2015:14), bahwa lingkungan fisik sekolah yang harus disiapkan bukan hanya bangunan sekolah berupa bangunan kelas namun juga lingkungan fisik lain yang turut menunjang sehingga lingkungan fisik sekolah merupakan keseluruhan lingkungan yang berada di sekolah baik bangunan utama untuk pembelajaran maupun bangunan penunjang atau lingkungan fisik penunjang pembelajaran. Lingkungan fisik itu antara lain: lingkungan sekolah yang bersih, kantin sekolah memenuhi syarat kesehatan, pengelolaan sampah yang terorganisir, pengelolaan air bersih dari pengambilan sumber air sampai dengan pengolahan limbah air, tersedianya ruang Usaha Kesehatan Sekolah (UKS ) yang memadai, toilet dan WC sesuai dengan kebutuhan siswa putera dan puteri, dan memiliki kebun sayur atau kebun tanaman obat sebagai sarana pendidikan.

\section{Perilaku Hidup Bersih dan Sehat}

Mewujudkan sekolah sehat bukan hanya sebatas mewujudkan sehat secara fisik namun juga kesehatan nonfisik atau kesehatan rohani. Perwujudan kesehatan rohani ini diwujudkan dengan sikap dan perilaku hidup sehat dari peserta didik. Indikator perilaku hidup bersih dan sehat di sekolah antara lain seperti yang disampaikan Nugraheni et al (2018: 78) bahwa kebiasaan hidup bersih dan sehat itu dapat dilihat dari kebiasaan di sekolah dalam hal mencuci tangan pakai sabun dengan air mengalir, makan jajanan yang sehat di kantin sekolah, kebiasaan tidak merokok, selalu membuang sampah pada tempatnya, memberantas jentik nyamuk dan kebiasaan melaksanakan olah raga di sekolah secara rutin bagi seluruh warga sekolah.

Penelitian yang dilakukan oleh Susana (2018: 6) menunjukkan bahwa dampak utama sekolah yang menerapkan perilaku hidup bersih dan sehat adalah tingginya pencapaian prestasi belajar para siswa, dampak positif ini terjadi karena adanya upaya sekolah untuk memberikan pengetahuan kepada siswa tentang pengetahuan akan kesehatan serta upaya sekolah untuk tetap menjadikan sekolah yang bersih sehingga kondusif untuk pembelajaran.

Berdasarkan pengertian-pengertian di atas maka yang dimaksud dengan sekolah sehat adalah sekolah yang memiliki kondisi lingkungan belajar yang sehat baik jasmani dan rohani yang ditandai dengan situasi sekolah yang bersih, hijau, indah, rindang dan memiliki perilaku hidup bersih dan sehat.

\section{Kepemimpinan Transformasional}

Banyak metode kepemimpinan yang dapat digunakan dalam metode pembinaan guru dan karyawan. Semua itu didesain sesuai dengan tujuan sekolah dengan situasi dan kondisi yang berbeda. Ketepatan dalam memilih dan menerapkan metode pembinaan dan kepemimpinan yang tepat akan menghasilkan ketercapaian tujuan secara maksimal. Salah satu metode kepemimpinan yang dapat digunakan untuk mewujudkan sekolah sehat adalah metode kepemimpinan transformasional.

Kepemimpinan transformasional menuntut pemimpin memiliki kompetensi manajerial yaitu kepemimpinan mengatur organisasinya dan kompetensi profesional yaitu kemampuan untuk merencanakan, melaksanakan dan mengevaluasi kegiatan sesuai visi organisasi. Seperti yang disampaikan Robbins (2008: 120), bahwa kepemimpinan transformasional pada prinsipnya adalah kepemimpinan yang menekankan pada kemampuan pemimpin dalam hal memberi motivasi atau semangat kepada yang dipimpin agar dapat melaksanakan tanggungjawabnya melebihi yang diharapkan, dan kemampuan pemimpin untuk menyusun dan menjabarkan visi organisasi ke dalam langkah-langkah praktis yang dapat dilaksanakan bawahannya.

Efektivitas kepemimpinan transformasional dapat dilihat dari proses yang dilakukan pimpinan terhadap bawahannya dan dapat dilihat dari hasil pekerjaan bersama. Seperti yang disampaikan Iensufiie, (2010: 2) bahwa efektifitas kepemimpinan transformasional dapat dilihat dari ciri yang ada yaitu, 1) terjadinya 
kesamaan tujuan antara pemimpin dengan yang dipimpin, 2) pemimpin mampu memberi motivasi dan menjadi motivasi bagi yang dipimpin, 3) terjadinya perubahan prestasi menuju prestasi yang lebih baik.

Kepala sekolah memiliki kedudukan yang strategis dalam meningkatkan prestasi sekolah, keinginan kepala sekolah meningkatkan prestasi tidak selalu mudah, karena itu kepemimpinan transformasional memiliki potensi untuk membantu kepala sekolah meningkatlkan prestasi dengan melakukan perubahan. Perubahan utama yang dilakukan adalah perubahan kepala sekolah dalam memahami visi dan misi sekolah. Pemahaman yang mendalam akan visi dan misi sekolah akan berpengaruh terhadap penjabaran visi dan misi oleh guru dan karyawan.

Peranan kepemimpinan transformasional memiliki peranan penting dalam meningkatkan kinerja guru serta meningkatkan kualitas sekolah. Upaya yang dapat dilakukan kepala sekolah adalah memberdayakan potensi sekolah sebagai modal perubahan.

Mengacu pada teori-teori di atas maka yang dimaksud dengan metode kepemimpinan transformasional dalam penulisan ini adalah kepemimpinan kepala sekolah dengan mengadakan perubahan atas kondisi sekolah dengan memberi motivasi kepada seluruh warga sekolah untuk dapat berpartisipasi secara aktif terhadap kegiatan sekolah.

Langkah-langkah yang dikerjakan kepala sekolah dalam mewujudkan sekolah sehat di SMPN 2 ini mengikuti langkah-langkah metode kepemimpinan transformasional yang diadaptasi dari Danim (2008: 62) yaitu kepala sekolah: 1) membangun perubahan, 2) membangun komunikasi, 3) memberi teladan, 4) mendorong kinerja bawahan, 5) mengharmoniskan lingkungan kerja, 6) memberdayakan bawahan, 7) bertindak atas dasar sistem nilai, 8) mengatasi situasi yang rumit.

\section{Pembahasan}

Hasil penulisan ini merupakan deskripsi dari sebuah tindakan yang dilakukan oleh kepala sekolah dalam mengembangkan sekolah, penulisan ini diperoleh berdasarkan pengamatan, pengalaman penulis dan pengkajian dokumen. Penulisan ini diawali dengan keprihatinan kepala sekolah terhadap lingkungan sekolah yang kotor. Hal ini terlihat dari kondisi lingkungan yang kurang bersih, tidak rapi, lingkungan yang gersang serta sarana prasarana yang tidak tersusun dengan rapi. Kondisi yang demikian tidak hanya terjadi pada lingkungan luar sekolah namun juga terjadi pada lingkungan dalam ruang, misalnya ruang kelas, ruang guru, ruang kepala sekolah, ruang perpustakaan, mushola, ruang laboratorium IPA dan Ruang Laboratorium Komputer serta sekolah belum memiliki kantin yang memadai, juga belum memiliki Ruang UKS yang memadai

Masalah lain yang berkaitan dengan hidup sehat yaitu bahwa siswa belum adanya kesadaran siswa dalam menciptakan budaya sehat bagi dirinya sendiri maupun bagi lingkungannya, hal ini terlihat secara sederhana bahwa siswa belum memiliki kesadaran yang optimal terhadap kebiasaan membuang sampah sembarangan. Siswa tidak memiliki wawasan tentang jajanan atau makanan yang sehat, akibatnya siswa jajan di luar sekolah yang berjejer para pedangang makanan, yang tidak terjamin kualitas bahan kualitas pembuatannnya dan kualitas penyajiannnya.

Kondisi lain bahwa guru dan karyawan kurang memiliki kepedulian dan ketertarikan terhadap lingkungan yang bersih. Guru terkonsentrasi pada kegiatan proses pembelajaran di kelas, bagaimana merencanakan pembelajaran, melaksanakan pembelajaran di kelas dan melakukan evaluasi. Pembelajaran yang dilakukan menitik beratkan pada pencapaian target materi pembelajaran.

Setelah penulis mengamati dan mengalami apa yang terjadi dengan lingkungan sekolah yang tidak sehat dan kebiasaan siswa yang tidak sehat, maka penulis berusaha untuk mengatasi kondisi yang kurang baik tersebut. Setelah itu penulis melakukan berbagai studi pustaka berbagai metode pengelolaan suatu organisasi maka diambil keputusan bahwa pendekatan transformasional sebagai strategi yang dapat diterapkan untuk mengatasi keadaan tersebut.

Dengan memperhatikan observasi di atas, maka kemudian penulis sebagai kepala sekolah mengambil suatu kebijakan dalam mengelola sekolah dengan mengacu pada manajemen sekolah dengan menerapkan strategi kepemimpinan transformasional. Penulis menyadari bahwa kondisi sekolah yang belum mencapai taraf yang ideal tidak pada tempatnya kalau penulis menyalahkan pihak lain, seperti siswa, guru atau karyawan, namun penulis setuju dengan pendapat yang mengatakan bahwa tidak ada sekolah yang baik yang tidak dipimpin oleh kepala sekolah yang baik, karena itu yang perlu diperbaiki adalah metode kepemimpinan kepala sekolah dengan menerapkan kepemimpinan transformasional.

Pelaksanaan kepemimpinan transformasional ini merupakan penerapan kepemimpinan 
yang dilaksanakan dalam pengelolaan sekolah di SMPN 2 Kasihan. Berdasarkan praktik penulis bahwa kepemimpinan transformasional dapat mewujudkan sekolah sehat di SMPN 2 Kasihan. kepemimpinan transformasional yang dilaksanakan mengacu pada langkah-langkah kepemimpinan transformasional yang diadaptasi dari Danim (2008: 62). Pelaksanaan kepemimpinan transformasional yang dilakukan kepala sekolah sebagai berikut:

Pertama, kepala sekolah membangun perubahan. Guna mewujudkan sekolah sehat maka yang dilakukan kepala sekolah adalah membangun perubahan. Perubahan yang dilakukan kepala sekolah adalah mengajak seluruh warga sekolah untuk merubah dari kondisi lingkungan sekolah yang belum sehat menjadi lingkungan yang sehat, serta mengajak warga sekolah melakukan perubahan dalam perilaku sehat dengan menerapkan perilaku hidup bersih dan sehat.

Kedua, kepala sekolah meyakinkan dan memberikan motivasi kepada guru dan karyawan. Supaya tidak timbul penolakan terhadap perubahan yang dikehendaki kepala sekolah. Kepala sekolah memperlihatkan wujud dari hasil akhir perubahan yaitu dengan menyampaikan salah satu unsur visi sekolah adalah mewujudkan peserta didik yang sehat, kepala sekolah memberikan gambaran tentang sekolah sehat yang diinginkan, dengan harapan semua warga sekolah sejak sekarang sudah mampu melihat dan merasakan sekolah sehat benar-benar terjadi. Hal ini sejalan dengan penelitian yang dilakukan oleh Maris et al (2016: 181) yang menunjukkan adanya pengaruh pemberian motivasi dalam kepemimpinan transformasional dengan peningkatan kinerja guru dan mutu sekolah sebesar 4.44 dengan katagori sangat tinggi.

Ketiga, membentuk tim kecil dan memberdayakan seluruh warga sekolah. Untuk mewujudkan sekolah sehat maka kepala sekolah membentuk tim kecil terlebih dahulu karena itu kepala sekolah dengan terlebih dahulu mensosialisasikan dan mendiskusikan tentang sekolah sehat kepada tim kecil. Pembentukan tim kecil ini adalah untuk melakukan penjajagan dan penguatan dan dukungan dari warga sekolah akan konsep sekolah sehat yang ditawarkan oleh kepala Sekolah. Kepala Sekolah berkeyakinan bahwa sebuah program sekolah akan mendapat dukungan yang kuat dari seluruh warga sekolah jika program tersebut telah terlebih dahulu dibahas bersama warga sekolah. Mengelola program perubahan saja bukan menjadi satusatunya jalan keluar, karena betapapun bagusnya ide perubahan, keberhasilannya sangat bergantung dari eksekusi para individu dalam lingkungan sekolah.

Keempat, membangun komunikasi. Kepala sekolah secara intensif melakukan komunikasi dengan guru karyawan baik secara formal melalui rapat atau briefing untuk menyampaikan program dan kebijakan sekolah yang dilakukan setiap hari senin, namun komunikasi dilakukan secara informal yaitu tidak hanya dilakukan dalam rapat tetapi juga dilakukan di luar rapat. Komunikasi formal maupun nonformal dilakukan untuk mengetahui sejauh mana perkembangan kemajuan program dari program pokja sekaligus menanyakan hambatan sekaligus memberi solusi terhadap hambatan yang ada. Cara ini nampaknya berpengaruh secara signifikan terhadap motivasi dan hasil kerja dari tiap guru dan karyawan, karena guru merasa diperhatikan dalam bekerja maupun dalam meraih prestasi.

Kelima, menghargai pendapat guru dan karyawan. Guru dan karyawan sekolah merupakan aset bagi kemajuan sekolah. Menghargai pendapat bagi kepala sekolah merupakan hal yang penting untuk memotivasi guru dan karyawan dalam bekerja dan berkarya.

Keenam, terlibat langsung. Guna membangun semangat para guru dan karyawan dalam melaksanakan tugas mewujudkan sekolah yang sehat maka kepala sekolah terlibat langsung dalam pekerjaan tim yang dibentuk. Posisi kepala sekolah disamping sebagai konseptor namun juga sebagai praktisi, misalnya ketika Tim Pokja Pilah Sampah bekerja memilah sampah maka kepala sekolah suatu saat ikut membantu juga memilah sampah, ketika Tim UKS menata ruang UKS kepala sekolah suatu saat ikut juga dalam kegiatan kebersihan UKS, namun keterlibatan langsung tersebut tidak dalam waktu sepenuhnya seperti yang dikerjakan anggota Pokja.

Ketujuh, memberi pelatihan dan mengadakan kerjasama. Untuk mewujudkan sekolah sehat maka kepala sekolah mengirim sebagian guru untuk mengikuti pelatihan pengelolaan sampah di Dinas Lingkungan Hidup Kabupaten Bantul dan sebagian guru mengikuti pelatihan pengelolaan sampah di Dinas Kesehatan Kabupaten Bantul. Hal ini didukung oleh penelitian yang dilakukan oleh Asmawan (2018: 52) yang menunjukkan bahwa adanya pengaruh yang positif kerjasama dengan masyarakat yang dilakukan dengan menggunakan kepemimpinan transformasional Kepala sekolah dalam mendukung gerakan literasi di sekolah.

Kedelapan, memberi teladan. Keteladanan kepala sekolah diwujudkan dalam bentuk: 1) 
disiplin, kepala sekolah menjadi teladan dalam kedisiplinan, misalnya disiplin waktu kehadiran, kepala sekolah hadir lebih pagi dari guru karyawan. Disiplin kehadiran, kepala sekolah selalu hadir di sekolah dengan tepat waktu, kepala sekolah menghargai waktu dalam setiap kegiatan sekolah. 2) Semangat, kepala sekolah harus menunjukkan penampilan diri yang bersemangat dalam bekerja, karena hal itu akan memberikan energi positif bagi para guru dan para siswa. Kepala sekolah berkeliling sekolah memantau lingkungan kelas memastikan pembelajaran berlangsung dengan tertib dan lancar. Berkeliling memastikan bahwa lingkungan sekolah dalam kondisi yang bersih. kepala sekolah memberi contoh nyata dalam hal kebersihan, misalnya ikut pungut sampah jika menemui sampah tidak ditempatnya. 3) Inovasi. Kepala sekolah membuat langkah-langkah baru dalam pengelolalan sekolah, hal ini akan merangsang dan memotivasi guru juga untuk melakukan inovasi baik dalam kegiatan di kelas maupun kegiatan di luar kelas. 4) Kepribadian. Kepala sekolah menunjukkkan pribadi yang baik dengan selalu mentaati peraturan dan tidak melanggar norma-norma yang berlaku. Maka sebagai kepala sekolah menghindari penyalahgunaan wewenang, menghindari penyalah gunaan keuangan dan menghindari pelanggaran kesusilaan. 5) Membangun hubungan kerja dan hubungan sosial, hubungan kepala sekolah dengan guru atau karyawan adalah hubungan profesionalisme namun juga mengedepankan aspek sosial dan kemanusiaan, karena itu guru harus dapat membangun komunikasi dengan ramah, sopan dengan prinsip saling menghargai sama lain. Hal ini didukung oleh penelitian yang dilakukan oleh Rahayu (2018: 196) bahwa keteladanan kepala sekolah dalam kepemimpinan transformasional berpengaruh terhadap rasa hormat guru kepada kepala sekolah dan menjadikan tingginya motivasi guru dalam mengerjakan tugas yang melebihi targetnya.

Rangkaian kegiatan telah dilaksanakan, berikut ini akan dibahas fenomena-fenomena penting sebagai hasil dari tindakan kepala sekolah dalam mewujudkan sekolah sehat. Pembahasan secara lebih terperinci dapat dijelaskan sebagai berikut.

Penerapan Kepemimpinan transformasional telah meningkatkan kualitas sekolah sehat. Peningkatan kualitas sebagai sekolah sehat dilihat dari dua aspek pengamatan yaitu; 1) Pengamatan terhadap lingkungan fisik sekolah, 2) Pengamatan terhadap perilaku hidup bersih dan sehat. Hasil pengamatan tersebut dapat dilihat dari Tabel 1 berikut.

Tabel 1. Kualitas Sekolah Sehat

\begin{tabular}{|c|c|c|c|c|}
\hline $\begin{array}{l}\text { Nilai Kualitas } \\
\text { Sekolah Sehat }\end{array}$ & \multicolumn{2}{|c|}{$\begin{array}{l}\text { Sebelum } \\
\text { Tindakan }\end{array}$} & \multicolumn{2}{|c|}{$\begin{array}{c}\text { Setelah } \\
\text { Tindakan }\end{array}$} \\
\hline Kondisi Lingkungan & 2.4 & Cukup & 3.4 & Baik \\
\hline $\begin{array}{l}\text { Perilaku Hidup } \\
\text { Bersih dan Sehat }\end{array}$ & 2.6 & Cukup & 3.88 & Baik \\
\hline $\begin{array}{l}\text { Rata-rata kualitas } \\
\text { Sekolah Sehat }\end{array}$ & 2.5 & Cukup & 3.64 & Baik \\
\hline
\end{tabular}

Dari Tabel 1 di atas dapat dijelaskan bahwa nilai rata-rata kualitas sekolah pada kondisi awal sebelum tindakan sebesar 2.50 dengan katagori "Cukup" dan pada setelah tindakan sebesar 3.64 dengan katagori "Baik". Dengan demikian kualitas sekolah dari Kondisi awal sebelum tindakan sampai dengan kondisi setelah tindakan terjadi peningkatan skor sebesar 1.14 atau kenaikan $45.60 \%$ dengan kualifikasi "Baik".

\section{Hasil Pengamatan Lingkungan Fisik Sekolah Sehat}

Peningkatan kualitas lingkungan sekolah dapat dijelaskan pada Tabel 2 berikut.

Tabel 2. Peningkatan kualitas lingkungan sekolah

\begin{tabular}{|c|c|c|c|c|}
\hline \multirow{2}{*}{\begin{tabular}{c}
\multicolumn{1}{c}{ INDIKATOR } \\
Memiliki lingkungan \\
sekolah bersih dan hijau
\end{tabular}} & \multicolumn{2}{|c|}{$\begin{array}{l}\text { Sebelum } \\
\text { Tindakan }\end{array}$} & \multicolumn{2}{|c|}{$\begin{array}{l}\text { Setelah } \\
\text { Tindakan }\end{array}$} \\
\hline & 2 & Kurang & 4 & Baik \\
\hline $\begin{array}{l}\text { Memiliki tempat sampah } \\
\text { dan pengelolaan sampah } \\
\text { yang memadai. }\end{array}$ & 3 & Cukup & 5 & $\begin{array}{c}\text { Sangat } \\
\text { Baik }\end{array}$ \\
\hline $\begin{array}{l}\text { Tersedia air bersih dan } \\
\text { sehat. }\end{array}$ & 3 & Cukup & 4 & Baik \\
\hline $\begin{array}{l}\text { Terdapat kantin sekolah } \\
\text { yang sehat. }\end{array}$ & 1 & $\begin{array}{l}\text { Sangat } \\
\text { kurang }\end{array}$ & 4 & Baik \\
\hline $\begin{array}{l}\text { Sanitasi air yang lancar, } \\
\text { tertutup dan tidak bau. }\end{array}$ & 3 & Cukup & 4 & Baik \\
\hline $\begin{array}{l}\text { Ruang kelas yang terang } \\
\text { dengan ventilasi cukup }\end{array}$ & 3 & Cukup & 4 & Baik \\
\hline $\begin{array}{l}\text { Sarpras pembelajaran } \\
\text { memenuhi standar } \\
\text { kesehatan dan pendidikan. }\end{array}$ & 3 & Cukup & 4 & Baik \\
\hline $\begin{array}{l}\text { Terdapat ruang UKS } \\
\text { dengan peralatan UKS } \\
\text { yang memadai }\end{array}$ & 2 & Kurang & 5 & $\begin{array}{c}\text { Sangat } \\
\text { Baik }\end{array}$ \\
\hline $\begin{array}{l}\text { Memiliki toilet (WC) } \\
\text { dengan ratio untuk siswi } 1 \\
: 25 \text { dan siswa } 1: 40\end{array}$ & 2 & Kurang & 4 & Baik \\
\hline $\begin{array}{l}\text { Memiliki taman/kebun } \\
\text { sekolah yang dimanfaatkan } \\
\text { untuk pembelajaran. }\end{array}$ & 2 & Kurang & 4 & Baik \\
\hline Jumlah Skor & 24 & & 34 & \\
\hline $\begin{array}{l}\text { Rata-Rata Kualitas } \\
\text { Lingkungan Sekolah sehat }\end{array}$ & 2.4 & Cukup & 3.4 & Baik \\
\hline
\end{tabular}


Hasil pengamatan lingkungan fisik sekolah sehat seperti yang tercantum dalam Tabel 2 di atas menunjukkan bahwa dari kondisi awal sampai dengan kondisi setelah tindakan menunjukkan peningkatan yang membaik. Nilai rata-rata kualitas sebelum tindakan sebesar 2.4 dengan kualifikasi kualitas "Cukup" dan setelah tindakan menunjukkan skor 3.4 dengan kualifikasi kualitas "Baik", dengan peningkatan skor sebesar $41.66 \%$. Secara rinci peningkatan kualitas tersebut dapat diterangkan sebagai berikut: nilai rata-rata kualitas halaman lingkungan sekolah, kondisi awal sebelum tindakan sebesar 2.00 dengan kualifikasi "Cukup" dan pada kondisi setelah tindakan sebesar 4.0 dengan kualifikasi kualitas "Baik". Dengan demikian dari sebelum tindakan sampai dengan kondisi setelah tindakan terdapat kenaikan skor rata-rata 2.00 atau terjadi kenaikan kualitas sebesar $100 \%$. Hal ini sejalan dengan yang disampaikan Arianto et al (2019: 22) bahwa strategi yang dapat dilakukan sekolah untuk mewujudkan sekolah sehat dengan cara memfasilitasi lingkungan sekolah antara lain dengan menyediakan tempat cuci tangan, tempat sampah serta tulisan motivasi menjaga kebersihan.

Tindakan kepala sekolah memberdayakan urusan sarana prasarana secara intensif berkontribusi terhadap peningkatan kualitas halaman dan lingkungan sekolah. Pendekatan dan apresiasi kepala sekolah secara informal kepada urusan sarana prasarana, staf urusan kebersihan dan urusan kesiswaan menaikkan kualitas tersebut. Hal ini senada dengan penelitian yang dilakukan Fauzuddin (2018: 82) bahwa kepemimpinan transformasional kepala sekolah dengan membentuk tim kerja yang kuat, mengembangkan sarana prasarana sekolah, serta memberikan apresiasi terhadap guru dan karyawan dapat meningkatkan prestasi sekolah.

Selain itu kepala sekolah melibatkan semua unsur dalam menjaga kebersihan menjadikan halaman sekolah dan kelas terlihat lebih bersih dan indah. Keteladanan kepala sekolah ikut membantu memungut sampah, merawat taman, merawat kolam ikan mendorong banyak orang untuk melakukan hal yang sama sehingga turut pula meningkatkan kualitas.

Ruang kelas siswa pada kondisi awal sebelum tindakan sampai dengan kondisi setelah tindakan menunjukkan kualitas yang meningkat. Tindakan kepala sekolah memberdayakan wali kelas untuk bersungguh sungguh membina kelas binaannya untuk membersihkan dan mengkreasikan kelasnya berkontribusi terhadap kenaikan kualitas ruang kelas. Nilai rata-rata kualitas ruang kelas siswa kondisi awal sebelum tindakan sebesar 3.00 pada kondisi setelah tindakan sebesar 4.00 dengan demikian terjadi kenaikan rata-rata sebesar 1.00 atau $33.33 \%$ dengan kualifikasi kualitas "Baik".

Kondisi itu terjadi karena setelah tindakan maka sebagian besar kelas sudah menghias dinding kelas dengan lukisan yang menarik yang dikerjakan oleh para siswa. Tindakan kepala sekolah yang melombakan kelas memotivasi siswa dan wali kelasnya untuk membenahi kelasnya berkontribusi terhadap peningkatan kualitas kelas. Kerjasama antara wali kelas dengan paguyuban orang tua murid kelas dan dengan urusan sarana prasarana sekolah memberi andil pula terhadap peningkatan kualitas.

Ruang Usaha Kesehatan Sekolah (UKS) menunjukkan kualitas meningkat, pengelolaan UKS di SMPN 2 Kasihan sejalan dengan Pedoman Pelaksanaan UKS di Sekolah (Direktorat Pendidikan Dasar, 2012: 5) bahwa pengembangan UKS meliputi pembinaan peserta didik, pembinaan pembina UKS dan Pembinaan sarana prasarana. Pengembangan sarana pendidikan dan pelayanan kesehatan UKS meliputi pengembangan ruang UKS yang mandiri, ruang tamu, ruang istirahat, ruang pelayanan pertama, tempat tidur, pengukur tinggi dan berat badan, obat-obatan sederhana, alat peraga kesehatan, buku pencatatan pemeriksaan kesehatan peserta didik, buku/lembar rujukan dan pojok baca kesehatan. Peningkatan kualitas ruang UKS dapat dilihat dari nilai rata-rata kualitas aspek Ruang UKS sebelum tindakan sebesar 2.00 dan pada Kondisi Setelah Tindakan sebesar 5.00, dengan demikian sebelum tindakan sampai dengan Kondisi Setelah Tindakan terdapat kenaikan kualitas sebesar 3.00 atau 150\% dengan kualifikasi kualitas "Sangat Baik".

Tindakan sekolah membangun ruang UKS tersendiri yang terpisah dengan ruang lain berkontribusi terhadap peningkatan kualitas UKS. Hal yang tidak kalah pentingnya dalam peningkatan kualitas UKS adalah kepala sekolah membangun komunikasi secara internal di dalam sekolah dan komunikasi secara eksternal dengan pihak luar sekolah sehingga terbangun kerjasama yang baik antara sekolah dengan Tim Pembina UKS Kecamatan Kasihan dan Tim Pembina UKS Kabupaten Bantul.

Penerapan Kepemimpinan transformasional telah meningkatkan kualitas sekolah, terutama dilihat dari aspek kantin sekolah. Pengelolaan Kantin SMPN 2 Kasihan mengacu pada kantin sekolah yang sehat seperti yang disampaikan 
Murdiati dan Amaliah (2013: 279) yaitu kantin yang menyediakan jajanan dengan syarat yaitu makanan yang tidak mengandung pewarna yang berbahaya bagi kesehatan, tidak mengandung pemanis buatan, tidak mengandung bahan pengawet dan senyawa yang berbahaya serta makanan yang dapat memenuhi kebutuhan kalori siswa. Gambaran kantin SMPN 2 Kasihan menunjukkan bahwa nilai rata-rata kualitas kantin menunjukkan kualitas yang meningkat yaitu, kondisi awal sebelum tindakan sebesar 1.00 dan pada kondisi setelah tindakan sebesar 4.00, dengan demikian terdapat kenaikan sebesar 3.00 atau $300 \%$ dengan kualifikasi kualitas "Sangat Baik".

Peningkatan kualitas kantin terjadi perbedaan yang sangat signifikan antara kondisi awal sebelum tindakan dengan setelah tindakan, karena sebelum tindakan sekolah tidak memiliki kantin akibatnya para siswa jajan pada para penjaja makanan dan minuman yang mangkal di depan sekolah yang tidak terjamin kebersihan, kesehatan dan ketercukupan gizinya. Setelah tindakan maka sekarang sekolah telah memiliki kantin yang representatif yang mencukupi dari segi kualitas, jajanan di kantin dipastikan bebas dari pengawet, bebas dari pewarna berbahaya dan terjamin keamanan dan kebersihannya.

Tindakan kepala sekolah yang berkontribusi besar terhadap peningkatan kualitas kantin adalah antara lain membangun jejaring. Kepala sekolah berhasil mengadakan kerjasama dengan Komite Sekolah, Puskesmas II Kasihan, Dinas Kesehatan Kabupaten Bantul, dan Universitas Aisyiah, dan Badan Pengawasan Obat Dan Makanan DIY untuk membimbing dan membina kantin sehat SMPN 2 Kasihan. Disamping itu kepala sekolah mengirim satu orang guru dan satu orang karyawan sebagai pengelola kantin untuk mengikuti pelatihan pengelolaan kantin di Dinas Kesehatan Kabupaten Bantul menjadikan kantin SMPN 2 lebih berkualitas.

Aspek pengelolaan sampah menunjukkan kualitas yang meningkat dibandingkan pada kondisi awal sebelum tindakan sampai dengan kondisi setelah tindakan. Pengelolaan sampah yang dilakukan di SMPN 2 Kasihan mengacu pada Pedoman Gerakan Sanitasi Sekolah (Direktorat Pembinaan Sekolah Menengah Pertama, 2015: 16) yaitu; 1) Pemilihan sampah organik dan nonorganik, 2) Pengolahan sampah dengan menerapkan konsep Reuse, Reduse dan Recycle. Reuse yaitu menggunakan sampahsampah menjadi barang yang dapat digunakan kembali, kemudian Reduce yaitu mengurangi sesuatu yang dapat menimbulkan sampah dan Recycle yaitu memanfaatkan sampah-sampah tertentu untuk diolah menjadi barang yang berguna, 3) sampah yang tidak berguna dikumpulkan untuk diangkut oleh petugas kebersihan ke Tempat Pembuangan Akhir (TPA). Nilai rata-rata kualitas pengelolaan sampah pada kondisi awal sebelum tindakan sebesar 3.00 pada kondisi setelah tindakan sebesar 5.00. dengan demikian terjadi kenaikan rata-rata sebesar 2.00 atau $66.67 \%$ dengan kualifikasi kualitas "Sangat Baik". Tindakan kepala sekolah membentuk "Kelompok Kerja Pengelolaan Sampah" yang terdiri dari siswa dengan bimbingan guru berkontribusi terhadap kenaikan kualitas pengelolaan sampah.

\section{Hasil Pengamatan Perilaku Hidup Bersih dan Sehat}

Budaya hidup bersih dan sehat dari kondisi awal sampai dengan kondisi setelah tindakan menunjukkan peningkatan yang membaik. Hal tersebut dapat dilihat pada Tabel 3 berikut.

Tabel 3. Budaya Hidup Bersih dan Sehat

\begin{tabular}{|c|c|c|c|c|}
\hline \multirow{2}{*}{\begin{tabular}{l}
\multicolumn{1}{c}{ INDIKATOR } \\
$\begin{array}{l}\text { Mencuci tangan dengan } \\
\text { air yang mengalir dan } \\
\text { memakai sabun }\end{array}$
\end{tabular}} & \multicolumn{2}{|c|}{$\begin{array}{l}\text { Sebelum } \\
\text { Tindakan }\end{array}$} & \multicolumn{2}{|c|}{$\begin{array}{l}\text { Setelah } \\
\text { Tindakan }\end{array}$} \\
\hline & 2 & Kurang & 4 & Baik \\
\hline $\begin{array}{l}\text { Mengonsumsi jajanan } \\
\text { sehat di kantin sekolah }\end{array}$ & 2 & Kurang & 5 & $\begin{array}{c}\text { Sangat } \\
\text { Baik }\end{array}$ \\
\hline $\begin{array}{l}\text { Membuang sampah pada } \\
\text { tempatnya }\end{array}$ & 3 & Cukup & 4 & Baik \\
\hline $\begin{array}{l}\text { Olahraga rutin di } \\
\text { sekolah }\end{array}$ & 3 & Cukup & 4 & Baik \\
\hline $\begin{array}{l}\text { Memberantas jentik } \\
\text { nyamuk }\end{array}$ & 2 & Kurang & 3 & Cukup \\
\hline $\begin{array}{l}\text { Tidak merokok di } \\
\text { sekolah }\end{array}$ & 4 & Baik & 4 & Baik \\
\hline $\begin{array}{l}\text { Menjaga berat badan } \\
\text { dan mengukur tinggi } \\
\text { badan }\end{array}$ & 3 & Cukup & 3 & Cukup \\
\hline $\begin{array}{l}\text { Menjaga kebersihan } \\
\text { jamban }\end{array}$ & 3 & Cukup & 4 & Baik \\
\hline Jumlah Skor & 22 & & 31 & \\
\hline Rata-rata kualitas & 2.75 & Cukup & 3.88 & Baik \\
\hline
\end{tabular}

Nilai rata-rata kualitas budaya hidup bersih dan sehat pada kondisi awal sebelum tindakan sebesar 2.75 dengan kualifikasi "Cukup" dan pada kondisi setelah tindakan sebesar 3.88 dengan kualifikasi kualitas "Baik". Dengan demikian dari sebelum tindakan sampai dengan kondisi setelah tindakan terdapat kenaikan skor rata-rata 1.13 atau terdapat kenaikan sebesar $40.90 \%$.

Peningkatan kualitas budaya hidup bersih dan sehat di SMPN 2 Kasihan sejalan dengan yang disampaikan Agustin (2017: 5) bahwa ciri 
siswa yang memiliki budaya hidup bersih dan sehat yaitu siswa memiliki kebiasaan cuci tangan dengan sabun sebelum dan sesudah makan, para siswa memiliki kebiasaan membuang sampah di tempatnya, siswa menggunakan tempat makanan yang sehat dengan menggunakan alat makan yang dibawa sendiri dari rumah, dan sekolah mengadakankan olah raga bersama secara rutin.

Berdasar pada analisis data dan penjelasan di atas maka dapat dikatakan bahwa, penerapan kepemimpinan transformasional di SMPN 2 Kasihan mendapat kualitas "Baik", sehingga penerapan Kepemimpinan transformasional dapat dikatakan meningkatkan kualitas sekolah sehat di SMPN 2 Kasihan.

Beberapa kendala yang muncul selama penerapan kepemimpinan transformasional dalam mewujudkan sekolah sehat yaitu; 1) terbatasnya sumber pendanaan, 2) siswa belum sepenuhnya melaksanakan budaya hidup sehat, karena bagi sebagian siswa belum tercipta budaya hidup sehat, 3) keterbatasan pengetahuan dan keterampilan guru tentang pengelolaan sekolah sehat, 4) terbatasnya lahan sekolah untuk menciptakan lingkungan yang rindang.

Strategi untuk mengatasi kendala yang ada maka untuk mengatasi keterbatasan dana maka yang dilakukan adalah memanfaatkan seoptimal mungkin dana Bantuan Operasional Sekolah dan dana Bantuan Operasional Sekolah Daerah (BOSDA) serta menjalin komunikasi dengan Komite Sekolah supaya dapat berkontribusi dengan program sekolah sehat. Untuk mengatasi siswa yang belum dapat melaksanakan perilaku hidup sehat, maka guru melakukan pengawasan dan pembimbingan secara individu dan kelompok tentang pentingnya perilaku hidup bersih dan sehat. Untuk mengatasi keterbatasan pemahaman dan ketrampilan mengelola sekolah sehat maka sekolah menghadirkan narasumber yang menguasasi pengelolaan sekolah sehat untuk melakukan sosialisasi dan pendampingan sekolah sehat. Guna mengatasi lahan sekolah yang sempit maka sekolah memanfaatkan sudutsudut sekolah untuk menciptakan kebun dan taman mini sekolah.

Penerapan metode kepemimpinan transformasional memberikan dampak dengan terwujudnya sekolah yang sehat, hal tersebut dapat dilihat dari terwujudnya lingkungan yang bersih dan indah, terwujudnya kantin yang memenuhi syarat, terwujudnya ruang UKS yang memenuhi syarat, terwujudnya perilaku warga sekolah yang bersih dan sehat, terwujudnya prestasi akademik yang meningkat, dan berhasil menjadi Juara 1 Lomba sekolah Sehat tingkat Kabupaten Bantul tahun 2019.

Manfaat penerapan kepemimpinan transformasional yaitu dapat digunakan sebagai salah satu alternatif bagi para kepala sekolah dalam mengembangkan dan meningkatkan kualitas sekolah sehat. Bagi pemangku kepentingan di dinas pendidikan kabupaten/kota dapat dijadikan bahan pertimbangan untuk mendorong sekolah-sekolah untuk menjadi sekolah yang memenuhi standar kesehatan.

Penerapan kepemimpinan transformasional ini dapat diteruskan dan dikembangkan karena keberhasilan suatu sekolah sangat tergantung kepemimpinan kepala sekolah, selain itu sekolah sehat sebagi standar pelayanan yang bermutu harus terus dijaga, dirawat dan dikembangkan. Sebagai proyeksi replikasi, bahwa penerapan kepemimpinan transformasional ini mudah untuk ditiru dilaksanakan dalam bentuk yang sama atau dengan modifikasi yang disesuaikan dengan kebutuhan dan keadaan setiap sekolah.

\section{Simpulan dan Saran}

Berdasarkan kegiatan kepala sekolah dengan menerapkan metode kepemimpinan transformasional, maka dapat disimpulkan bahwa kepemimpinan transformasional mampu mewujudkan sekolah sehat di SMPN 2 Kasihan Bantul. Aspek-aspek yang sebelum tindakan terdapat kekurangan jika dilihat dari sekolah sehat telah mengalami peningkatan kualitas dan menunjukkan hasil ke arah yang positif. Mulai dari keadaan halaman dan lingkungan sekolah, keadaan ruang kelas, keadaan ruang UKS, keadaan keadaan kantin, serta perilaku hidup bersih dan sehat sudah mengalami perubahan ke arah lebih baik.

Hasil penerapan metode kepemimpinan transformasional menunjukkan bahwa nilai ratarata sekolah sehat sebelum dilaksanakan tindakan sebesar 2.5 dengan kualifikasi Cukup dan setelah dilakukan tindakan meningkat menjadi rata-rata 3.64 atau meningkat $45.6 \%$ dengan kualifikasi Baik. Kualitas lingkungan sekolah mengalami peningkatan dari rata-rata 2.4 sebelum tindakan dan setelah tindakan mencapai rata-rata 3.4 atau peningkatan sebesar $41.66 \%$. Kualitas budaya hidup bersih dan sehat juga mengalami peningkatan dari sebelum tindakan rata-rata 2.75 atau Cukup menjadi ratarata 3.88 atau Baik, dengan peningkatan kualitas sebesar $41.09 \%$. Berdasarkan hasil penelitian tersebut maka dapat disimpulkan bahwa metode kepemimpinan transformasional dapat mewujudkan sekolah sehat di SMPN 2 Kasihan. 
Berdasarkan pada kesimpulan di atas, ada beberapa saran yang ditujukan kepada kepala sekolah, pengawas sekolah dan instansi terkait yaitu; 1) kepala sekolah memegang peranan yang sangat penting dalam pengembangan sekolah, oleh karena itu perlu dipertimbangkan untuk menggunakan berbagai metode kepemimpinan, tentu pilihan menggunakan metode ini disesuaikan dengan kondisi nyata di sekolah dan permasalahan yang ada sehingga dalam penyelesaian masalah harus dipilih metode yang tepat untuk mendapatkan hasil yang maksimal, 2) pembinaan kepala sekolah oleh pengawas sekolah sangat diperlukan seperti kegiatan pembinaan, kegiatan Musyawarah Kerja Kepala Sekolah, pelatihan-pelatihan dan pelaksanaan kegiatan-kegiatan ilmiah seperti seminar, simposium, lokakarya dan konferensi semua perlu diterapkan untuk mewujukan sumberdaya kepala sekolah yang benar-benar profesional. Metode kepemimpinan transformasional ini dimungkinkan dapat juga diterapkan di sekolah lain dengan kondisi permasalahan yang hampir sama.

\section{Daftar Pustaka}

Agustin, Retno Ardani. (2017). Perilaku Kesehatan Anak Sekolah. Yogyakarta: CV. Pustaka Abadi.

Arianto, Ismail, Clara Aji Sukmo, Achmad Husen, Widiastuti dan Rusdi. (2019). Pedoman Sekolah Sehat Berkarakter Untuk Sekolah Menengah Pertama. Jakarta: Kementerian Pendidikan dan Kebudayaan Direktorat Jenderal Pendidikan Dasar Dan Menengah.

Asmawan, Moh.Chairil (2018). Kepemimpinan Transformasional Kepala Sekolah Dalam Mendukung Gerakan Litarasi Sekolah. JPIPS. Jurnal Pendidikan dan Ilmu Sosial. Volume 28, No 1. Juni 2018

Badan Penelitian dan Pengembangan Kementerian Pendidikan dan Kebudayaan. (2017). Peningkatan Derajat Manusia Melalui Pendidikan. Jakarta: Balitbang, Kemendikbud.

Danim, Sudarwan dan Suparno. (2009). Manajemen dan Kepemimpinan Transformasional Kepala Sekolah. Jakarta: Rineka Cipta.

Departemen Kesehatan RI. (2009). UndangUndang Republik Indonesia Nomor 36 Tahun 2009 Tentang Kesehatan. Jakarta: Kementerian Kesehatan RI.

Depdiknas. (2003). Undang-undang nomor 20 Tahun 2003 tentang Sistem Pendidikan Nasional. Jakarta: Biro Hukum dan Organisasi Depdiknas.
Depdiknas. (2005). Peraturan Pemerintah No.19 Tahun 2005 tentang Standar Nasional Pendidikan. Jakarta

Direktorat Pembinaan Sekolah Menengah Pertama. (2015). Pedoman Gerakan Sanitasi Sekolah. Jakarta: Direktorat Pembinaan Sekolah Menengah Pertama.

Direktorat Pendidikan Dasar. (2012). Pedoman Pelaksanaan UKS di Sekolah. Jakarta : Direktorat Pendidikan Dasar.

Fauzuddin. (2018). Kepemimpinan Transformasional Kepala Sekolah Dalam Meningkatkan Prestasi Sekolah. Jurnal Belantika Pendidikan. Volume (2) November 2018.

Iensufiie, Tikno. (2010). Leadhership untuk Profesional dan Mahasiswa. Jakarta: Erlangga.

Kemendiknas. (2009). Panduan Pengembangan Model Sekolah Sehat di Indonesia. Jakarta: Direktorat Jenderal Pendidikan Dasar.

Kementerian Pendidikan dan Kebudayaan. (2015). Pedoman Gerakan Sekolah Sehat, Aman, Ramah Anak, dan Menyenangkan. Jakarta: Kementerian Pendidikan dan Kebudayaan.

Maris, Intan Silvana, Aan Komariah dan Abubakar. (2016). Kepemimpinan Transformasional Kepala Sekolah, Kinerja Guru Dan Mutu Sekolah. Jurnal Administrasi Pendidikan Vo. XXIII No.2 Tahun 2016

Murdiati, Agnes dan Amaliah. (2013). Panduan Penyiapan Pangan Untuk Semua. Jakarta : Kencana

Nugraheni, Hermien, Sofwan Indarjo, dan Suhat. (2018). Buku Ajar Promosi Kesehatan Berbasis Sekolah . Yogyakarta : Deepublish

Rahayu, Renita Silvia. (2018). Implementasi Kepemimpinan Transformasional Kepala Sekolah Dasar Negeri. Jurnal Manajemen dan Supervisi Pendidikan. Volume 2 nomor 3 Juli 2018.

Robbins, Stephen P. (2008). Perilaku Organisasi, Konsep Kontroversi, Aplikasi. Jilid 1 Edisi Bahasa Indonesia. Jakarta: Prenhallindo.

Susana, Anna (2018). Manajemen Kesehatan Peserta Didik Sekolah Dasar. Jurnal Administrasi Pendidikan Vol.XXV No.1 April 2018. UPI. Bandung: Universitas Pendidikan Indonesia. 